\title{
SINDICALISMO REVOLUCIONÁRIO EM PORTUGAL
}

Joana Dias Pereira*

Resumo: A conjuntura em que o Sindicalismo Revolucionário se difunde entre os trabalhadores organizados portugueses coincide com o período balizado pela recessão económica dos finais do século XIX e o seu trágico desfecho - a imposição de uma solução autoritária. É nesta época que a classe operária emerge como novo protagonista social em Portugal, opondo-se aos pilares do regime vigente - o capitalismo, o parlamentarismo e o domínio burguês. Desde meados do século XIX que as suas associações de classe crescem em número de associados, lideradas pelo Partido Socialista Português, que Ihes incutia um carácter puramente reformista. É na alvorada do século XX que o seu movimento muda de feição, adoptando paulatinamente a aç̧ão directa contra o patronato como única forma de fazer frente ao crescente aumento da carestia de vida, que caracteriza todo este período. A eficácia da nova táctica, importada de França, transforma radicalmente o movimento dos trabalhadores, atraindo anarquistas, radicalizando socialistas e, sobretudo, transformando as velhas associações de classe em sindicatos modernos, que mobilizarão de facto as massas operárias. O poder de atracção do Sindicalismo Revolucionário residia nas conquistas parciais e imediatas que satisfaziam os reformistas e as massas trabalhadoras despolitizadas, não obstante o seu propósito - a transformação radical da sociedade através da substituição do capitalismo pela gestão sindical. Todavia, estes postulados não atravessam a crise do sistema liberal incólumes. Fenómenos como a Revolução Política, a Grande Guerra, a Revolução Russa e a reacção patronal determinam a evolução ideológica, no 1ㅇq quartel do século XX, dos dirigentes operários e das próprias escolas socialistas.

Palavras-chaves: Movimento Operário; Evolução Ideológica; Conjuntura Histórica; Século XX.

Abstract: The circumstances under which the revolutionary unionism influences organized portuguese workers coincides with the economic recession of late 19th century and it's tragic outcome - the imposing of an authoritarian solution. In the same period, the workingclass emerges as a new social protagonist in Portugal, opposing the regime pillars capitalism, parliamentarianism and the bourgeois domain. Since the mid-19th century, their associations grow in number, led by the reformist Portuguese Socialist Party. It is at the dawn of the 20th century that the movement changes by slowly adopting direct action against employers, as the only way to confront the growing cost of living which characterizes the whole period. The effectiveness of this new tactic, imported from France, transforms the workers movement radically, attracting anarchists, hardening socialists and, especially, transforming the old class associations into real trade unions, mobilizing workers. The attractiveness of revolutionary unionism came from partial and immediate gains that satisfied the reformers and the apolitical working masses, despite it's purpose - the radical

\footnotetext{
* Investigadora do Instituto de História Contemporânea da Faculdade de Ciências Sociais e Humanas da Universidade Nova de Lisboa. Mestre em História Contemporânea, com tese consagrada à história do movimento operário português. Doutoranda em História Contemporânea com investigação dedicada à industrialização em Portugal. joana.dp@gmail.com
} 
transformation of society, replacing capitalism by trade union management. However, these postulates did not pass the liberal crises unchanged. Phenomena such as the political revolution, the Great War, the Russian Revolution and the employer's reaction, in the 1st quarter of the 20th century, determine the ideological evolution of workers' leaders and Socialists schools.

Keywords: Workers movement; Ideological evolution; historical conjuncture; XX Century.

\section{INTRODUÇÃO DO SINDICALISMO REVOLUCIONÁRIO EM PORTUGAL}

Diversos autores têm vindo a apontar a Carta de Amiens de 1906 como a cartilha que o sindicalismo português seguiu durante a Primeira República Portuguesa. É a partir de 1908 que os seus postulados são divulgados na imprensa e nas publicações operárias nacionais.

Ainda antes da Tese Organização Social Sindicalista ser aprovada no I Congresso Sindicalista de 1909, Emílio Costa interrogava-se “Parlamentos ou Sindicatos?"1 Este intelectual libertário, que conhecia pessoalmente o próprio Lagardelle, escrevia no Les Temps Nouveaux e seguiu a conceptualização da doutrina e os debates por esta originados de perto, tendo escrito inúmeros artigos na imprensa portuguesa sobre o tema e realizando algumas conferências em associações de classe.

Todavia, os seus escritos doutrinários não encontravam eco nas classes trabalhadoras, e foi necessário a União dias Artes Gráphicas Portuguesas enviar um delegado $^{2}$ ao V Congresso Internacional Typográfico de 1907, para que este, ao sublinhar os resultados práticos daquelas teorias, visse entusiasmar o operariado português.

As surpreendentes conquistas dos tipógrafos franceses chegaram à associação de classe portuguesa, motivando um grupo de cinco operários tipógrafos. ${ }^{3}$ Em Fevereiro de 1908, estes convocam uma reunião entre destacados militantes anarquistas e socialistas, propondo-Ihes a publicação de um periódico sindicalista unitário. Desta reunião resultou a criação do "Grupo de Propaganda Social», que integrava membros das duas escolas, e que

\footnotetext{
${ }^{1}$ A Lucta, Agosto e Setembro de 1906.

2 Augusto César dos Santos foi representar a União das Artes Gráphicas Portuguesas ao V Congresso Internacional Typográfico 1907. É responsável pelos artigos difusores das conquistas do movimento sindical francês em A Greve.

${ }^{3}$ Evaristo Ferreira, Alfredo Freitas, Fausto Graça, Francisco Judicibios, Alfredo Duarte Laureano e Alexandre Vieira.
} 
no aniversário da Comuna de Paris - 18 de Março -, faz publicar o primeiro número do diário sindicalista $A$ Greve.

A Greve constitui a primeira experiência do que viria a ser a unidade no seio do movimento operário, com base na independência doutrinal e face ao poder político, princípios norteadores do Sindicalismo Revolucionário. De facto, entre os seus redactores contavam-se destacados membros do PSP, como Augusto César Santos e César Nogueira, e eminentes intelectuais anarquistas, como Hilário Marques ou Pinto Quartim, bem como Jorge Coutinho, que viria a ser o primeiro secretário-geral da corrente sindicalista.

Este periódico reflecte apenas um conhecimento empírico do Sindicalismo Revolucionário, não sendo enunciados os seus princípios teóricos, mas apenas os seus resultados práticos. Todavia, não há dúvida de que novas idéias começavam a ser arremessadas contra a hegemonia da social-democracia. ${ }^{4}$

A idéia de conciliação de classes, essa "malfazeja tuba pacificadora", é fortemente combatida. O editorial de 18 de Abril defende que esse conceito é o pior inimigo do progresso social, "mais nocivo porque empata, mais perigoso porque desorienta". ${ }^{5}$ A acção directa começa a ser paulatinamente propagandeada neste periódico - a greve como resposta ao lock-out patronal, para que as classes se possam enfrentar sem intermediários ${ }^{6}$, - label, a sabotagem e a Boycotage, como formas legítimas de defesa dos interesses operários. $^{7}$

Porém, como o próprio Alexandre Vieira - redactor principal deste órgão - admite, estes militantes pouco conheciam da doutrina. Os ecos do Sindicalismo Revolucionário francês só viriam a ter ressonância junto do operariado português quando Emílio Costa traduziu algumas das suas obras de referência. ${ }^{8}$

Em 1909, a Bertrand começa a editar uma colecção designada Biblioteca do Movimento Social, cujos volumes correspondem à tradução de Emílio Costa das principais obras teóricas do Sindicalismo Revolucionário, publicadas um ano antes pela Bibliothèque du Mouvement Socialiste. Curiosamente negligenciou o seu primeiro volume - $A$ decomposição

\footnotetext{
" “A humanidade não está dividida em partidos políticos, em escolas partidárias, mas em duas classes diametralmente opostas: - uma que trabalha e que produz, e que no entanto é victima de todas as injustiças; outra que explora e gosa, cheia de comodidades e fausto." A Greve, 25 de Março de 1908, p. 1.

${ }^{5}$ A Greve, 18 de Abril de 1908, p. 1.

${ }^{6}$ A Greve, 31 de Março e 1 de Abril de 1908, p. 1.

${ }^{7}$ A Greve, 28 de Junho de 1908, p. 1.

${ }^{8}$ VIEIRA, Alexandre. Para a História do Sindicalismo em Portugal. Lisboa: Seara Nova, 1970. p. 22-23.
} 
do marxismo, de George Sorel, incontornável para o sindicalismo francês. ${ }^{9}$ No mesmo ano, a Biblioteca de A Sementeira editara a obra de Paul Delessaule - A Confederação Geral do Trabalho: história, constituição, fins, meios. ${ }^{10}$

Estas idéias encontram finalmente eco nos jornais corporativos, chegando a motivar divisões nas associações de classe e a criação de novos periódicos. Por exemplo, os manipuladores de tabaco romperam com o reformista $A$ Voz do Proletário, iniciando a edição de A Defesa Operária, com o objectivo de "concorrer para levantar o operariado em geral da sua funesta apathia (...) entendendo que a questão económica é a base fundamental do problema social" ${ }^{11}$

Os manipuladores de tabaco encontravam-se em sintonia com a Federação das Associações Operárias de Coimbra, transcrevendo do seu novo O Despertar artigos que propagandeavam "o sindicalismo" como solução para "resolver o problema operário, extinguir o salariato, fazer a revolução social". ${ }^{12}$

No Porto ${ }^{13}$, "para o desenvolvimento na mentalidade da classe operária no sentido revolucionário resolveu um grupo de camaradas fundar um centro, no qual se estabelecessem conferências, palestras (...) O centro biblioteca de estudos sociaes iniciou uma série de conferências e publicou também um pequeno jornal de boa propaganda sindicalista, O Libertador". ${ }^{14}$

A comissão executiva do congresso sindicalista de 1909, primeira assembléia de orientação revolucionária, dividiu-se em subcomissões, uma das quais destinada "à propaganda do sindicalismo". "Mandou vir de França, folhetos, estatutos de Sindicatos, de Federações, de Uniões e de Confederação Geral, assim como jornaes, brochuras, etc. (...) não poupando mesmo os amigos, como Sá Vianna, Emílio Costa e outros, que Ihe fizeram

\footnotetext{
${ }^{9}$ A acção sindicalista, por Griffuelhes; A Confederação Geral do Trabalho, por Émile Pouget; Sindicalismo e socialismo, por H. Lagardelle, A. Labriola, B. Kritchewsky, R. Michels e A. V. Grifuelles; O Sindicalismo e revolução, por M. Pierrot.

${ }^{10}$ Esta colecção era da responsabilidade das Edições do Grupo "Acção Diréta", que incluía obras de Malatesta, Liste e Kropotkine.

11 “A nossa missão" in A Defesa Operária, 7 de Março de 1909, p. 1.

12 "Sindicalismo e anarquismo" in O Despertar, 21 de Novembro de 1908, p. 1.

13 "A greve geral: conclusões" in O Libertador, Novembro de 1908, p. 3.

14 “Correspondência" in O Despertar, 19 de Dezembro de 1908, p. 1.
} 
algumas conferências". ${ }^{15}$ Finalmente, esta comissão foi responsável igualmente pela publicação do órgão sindical.

Pouco mais de um mês após a implantação da República, a 13 de Novembro de 1910, é publicado o primeiro número de $O$ Sindicalista. ${ }^{16} \mathrm{O}$ editorial deste primeiro número é claro ao afirmar-se sindicalista e ao sublinhar que o seu objectivo é "destruir o salariato." 0 periódico tinha por missão "expor e definir novos processos de lucta, novas formas de organização." Este foi o papel principal do "semanário defensor da classe trabalhadora."17

O Sindicalista de 1910, ao contrário de A Greve de 1908, reflecte já um conhecimento profundo da doutrina nascida em França. As frases de Sorel e seus partidários povoam toda a publicação, ao mesmo tempo que são transcritos muitos dos textos fundamentais do Sindicalismo Revolucionário. Sintomático é, por exemplo, o Folhetim do Sindicalista, uma secção do jornal, que transcreve integralmente obras como o $A B C$ do sindicalista: origem, funcionamento, meios de acção, fins do agrupamento sindical, de Georges Yvevot.

Os militantes portugueses estavam entusiasmados com a eficácia do sindicalismo francês e, consequentemente, ávidos de conhecer a teoria que permitia alcançar aqueles resultados práticos. Para além das obras traduzidas, os militantes portugueses também ensaiaram as suas próprias teorizações da temática. Destacados dirigentes operários e alguns dos intelectuais que se uniram ao movimento dissertaram sobre as vantagens da acção directa sobre a acção legal e concorreram com o seu esforço para a difusão do novo sindicalismo - o revolucionário.

Em 1911 são publicadas duas obras fundamentais para o desenvolvimento teórico do sindicalismo em Portugal: Acção Directa e Acção Legal, de Emílio Costa, e Sindicalismo e Acção Directa, de Manuel Joaquim de Sousa.

Entre 1908 e 1911, a imprensa operária conhece o seu primeiro período áureo do século XX. Surgem uma média de cerca de três dezenas de novas publicações por ano, destacando-se as de tendência sindicalista e as porta-vozes das associações de classe, que cada vez mais fazem a apologia desta doutrina. De facto, à revelia dos periódicos de influência anarquista ou socialista, emergem quase seis centenas de novas publicações

\footnotetext{
15 “Relatório da Comissão Executiva do Congresso Operário e Sindical e 1909" in O Sindicalista, 12 de Fevereiro de 1911, p. 2.

${ }^{16}$ Este periódico, que perdurará até 1916 com interrupções, era dirigido por António Evaristo, editado por Alfredo Laureano e propriedade do Grupo Sindicalista.

${ }^{17}$ O Sindicalista, 13 de Novembro de 1910, p. 1.
} 
independentes destinadas unicamente à defesa dos interesses das classes, ainda que muitos dos seus dinamizadores proviessem das hostes anarquistas.

\section{O Sindicalismo ReVoluCiOnÁRIO e A ReVoluÇÃo Política}

Quando a burguesia europeia impôs o seu regime económico, social e político, destronando progressivamente o feudalismo, a aristocracia e a monarquia, demonstrou aos trabalhadores que a transformação social era realizável.

No século XIX, vários pensadores dividiram-se ao planear a revolução social e diferentes tentativas de concretização foram frustradas - a via parlamentar não logrou a melhoria gradual das condições de vida do operariado; e a Comuna de Paris, que prometia transformá-las rápida e radicalmente, foi esmagada.

Estas experiências terão contribuído para a consciencialização dos dirigentes operários face à ineficácia do colaboracionismo e da precipitação revolucionária, compreendendo que só pelo fortalecimento gradual das suas organizações autónomas poderiam atingir os dois objectivos - pequenas regalias a curto prazo e a emancipação no futuro.

As classes trabalhadoras, que em muitos contextos nacionais haviam ajudado a burguesia a tomar o poder, revoltaram-se contra os novos senhores e foram facilmente convencidas a lutar pela sua deposição.

"Os próprios trabalhadores», apoiados por pensadores socialistas e anarquistas, enunciaram nos finais do século os postulados da sua emancipação, opondo a socialização dos meios de produção ao capitalismo, a gestão operária à hegemonia burguesa, o federalismo solidário ao individualismo liberal.

A via insurreccional, que os próprios inimigos Ihes haviam ensinado, foi eleita, mas não antes de se criar o germe da nova sociedade no seio do capitalismo. Tal como os representantes da burguesia tinham criado parlamentos em monarquia, os delegados operários criariam a organização sindical, opondo a luta reivindicativa ao debate parlamentar e, posteriormente, a greve geral à revolução política.

Esta dialéctica desenvolveu-se primordialmente em França, onde a revolução burguesa antecedera as dos restantes países. Todavia, o internacionalismo operário garantiu 
a difusão destas idéias que chegaram a Portugal ainda antes da revolução republicana portuguesa.

Em contexto nacional, os republicanos na oposição souberam colorir o seu programa de socialismo, prometendo de uma só vez resolver a questão política e social. Muitos trabalhadores esperaram que o seu discurso fosse sincero, os mais radicais preferiram testar as suas próprias forças. O operariado dividiu-se entre as promessas republicanas e as conquistas efectivas da CGT francesa.

A condição desesperada em que vivia não será estranha à opção de lutar directamente contra o patronato, em vez de esperar que os novos governantes o fizessem em seu nome. A introdução do Sindicalismo Revolucionário em Portugal foi como aproximar - lume da estopa: crescentemente vitimados pela carestia de vida, sem representação política ou política social, os trabalhadores portugueses não tinham porque não utilizar a acção directa.

A oportunidade de um regime em transformação não foi perdida e os seus divulgadores puderam comprovar a sua eficácia, acompanhando o período de consolidação do poder de uma onda grevista inédita. É desta forma que a direcção do PSP, empenhada em tomar o balanço da revolução política, foi ultrapassada pela corrente revolucionária que crescia no seio das associações de classe.

O anarquismo operário viu na táctica apregoada por esta nova doutrina a possibilidade de se ligar finalmente à luta dos trabalhadores. O socialismo possibilista ${ }^{18}$ também viu com bons olhos a independência da luta sindical face à revolução burguesa.

As vantagens da revolução política eram discutíveis e de facto largamente discutidas, contemporaneamente à difusão do Sindicalismo Revolucionário. No plano teórico, anarquistas e socialistas não podiam negar o avanço histórico que representava a implantação da República, enquanto que os sindicalistas se preocupavam mais com os seus efeitos práticos.

De facto o poder de atração do ideário republicano constitui-se como o principal obstáculo à conquista dos trabalhadores para a acção directa e para o repúdio do

\footnotetext{
${ }^{18}$ Distinguiam-se pelo seu apoliticismo e reformismo. Inspirados por B. Balon e P. Brousse, são os percursores da defesa da autonomia sindical face ao PSP, quando levam a Conferência das Associações de Classe de 1882 a proclamar este princípio. Luiz Figueiredo, director de $O$ Trabalho de Setúbal é um dos elementos destacados desta corrente. MÓNICA,Maria Filomena. O Movimento Socialista em Portugal. p. 6.
} 
colaboracionismo. Ou seja, se a democracia política garantiria melhores condições de agitação e propaganda ao sindicalismo, o republicanismo apresentava-se como uma arma ideológica, bastante sedutora, nas mãos da burguesia.

Todavia, patronato e Estado burguês não tardaram em desmascararem-se. E apesar dos políticos republicanos procurarem enquadrar as classes trabalhadoras no novo regime, 0 patronato não estava disposto a discutir o seu poder absoluto com os operários, não compactuando com, nas palavras de Alfredo da Silva ${ }^{19}$, "conversas com comissões de trabalho e outras fantasias de ocasião."20

De facto, a atitude do potentado industrial não terá sido estranha ao conteúdo do «decreto-burla» ${ }^{21}$ de Brito Camacho ${ }^{22}$, publicado durante a primeira greve nas suas fábricas do Barreiro, dois meses após a revolução. Os republicanos sabiam bem que se tratava "dos interesses duma empresa que fez uma grande obra, ainda incompleta". ${ }^{23}$

A tensão social instala-se na Primeira República Portuguesa e os seus ministérios cedem facilmente aos interesses patronais, fazendo as teses revolucionárias ganhar um sentido incontestável, ao considerarem a acção política inútil aos trabalhadores. Paralelamente, a eficácia da acção directa criava a esperança de um desfecho favorável à classe trabalhadora.

Em vésperas do 5 de Outubro ${ }^{24}$, o Partido Socialista Português (PSP) procurava restabelecer a sua hegemonia no movimento sindical, esperançado que a revolução política finalmente the concedesse a oportunidade de reformar o Estado capitalista. Todavia, os sindicalistas revolucionários, apoiados por anarquistas operários e por alguns socialistas, abandonaram o congresso reformista de Julho de 1909, para criar o germe do movimento operário que marcará a I República Portuguesa.

\footnotetext{
${ }^{19}$ Alfredo da Silva era um dos principais industriais portugueses da época e acérrimo defensor do regime monárquico. Viria mais tarde a apoiar o interregno ditatorial de Sidónio Pais (1917-1918) e posteriormente o regime fascista.

${ }^{20}$ Alfredo da Silva, "Acta no 636 da Sessão Extraordinária dos Conselhos de Administração e Fiscal”, Livro 10 do Conselho de Administração da Companhia União Fabril, 6 de Dezembro de 1910. Cit. por Vanessa de Almeida. A Greve de Solidariedade na CUF do Barreiro em 1910. Trabalho realizado no âmbito do Mestrado em Antropologia da FCSH da UNL em 2007.

${ }^{21}$ Decreto que legaliza a greve mas também o lock out patronal das fábricas, protegendo claramente o patronato e os «fura-greves».

${ }^{22}$ Ministro do governo provisório.

${ }^{23}$ Brito Camacho, A Luta, 8 de Dezembro de 1910, p. 1.

${ }^{24}$ Data da revolução republicana de 1910.
} 
Quando em 1911 se voltam a reunir em congresso as associações de classe de tendência revolucionária, o panorama do movimento operário português era indubitavelmente outro: as associações aderentes à nova doutrina haviam crescido em número, em militância, e, principalmente, em actividade, sendo responsáveis pela onda grevista que assolou os primeiros anos republicanos.

Os novos governantes, muito embora tenham elogiado e usufruído do movimento para a tomada do poder, irão reprimir violentamente a acção directa, manifestando a sua profunda hostilidade ao movimento autónomo dos trabalhadores. A resolução da grave situação económica e social das classes trabalhadoras por via constitucional não será igualmente alcançada durante a 1a República.

A partir de 1912, já com o apoio dos militares e apoiada no militarismo, que recrudescia em toda a Europa, a República definiu a sua orientação face à corrente revolucionária do sindicalismo, esmagando o movimento, prendendo os dirigentes e proibindo a propaganda. Experimentará ocasionalmente favorecer o reformismo, com o apoio do PSP, mas face à sua ineficácia, abandonará rapidamente esses projectos. 0 contexto guerrista favorecia os métodos repressivos mas, paradoxalmente, a unidade dos trabalhadores.

De facto, é na decorrência da desilusão republicana e numa conjuntura particularmente dificil para o movimento operário que a corrente revolucionária do sindicalismo português, inspirada na Carta de Amiens da CGT Francesa, irá conseguir a unificação das associações de classe no I Congresso Nacional Operário, em Março de 1914, aprovando um conjunto de resoluções que adoptam e adaptam postulados marxistas e libertários, conciliando socialistas, acratas e sindicalistas puros.

Se o carácter unitário do Sindicalismo Revolucionário francês teve origem numa dinâmica de vitória, em Portugal os postulados mínimos que uniram socialistas, anarquistas e "sindicalistas puros» não constituíram um programa para a revolução mas para a resistência.

De facto, na primeira ofensiva operária do século $X X$, os revolucionários e os reformistas portugueses seguiram caminhos divergentes, quando se organizaram os Congressos Sindicalistas de 1909 e 1911 à revelia das antigas federações operárias socialistas. Só quando foi necessário resistir ao refluxo da luta reivindicativa e à conjuntura de guerra, se concretizou o I Congresso Nacional Operário. Neste, sim, as cedências mútuas 
permitiram realizar o sonho de $A$ Greve, em 1908, unindo todas as tendências sociais na União Operária Nacional (UON).

\section{O SINDICALISMO REVOLUCIONÁRIO PORTUGUÊS E A GRANDE GUERRA}

O Sindicalismo Revolucionário foi contemporâneo do militarismo que assolou a Europa na segunda década do século $X X$ e, em última instância, foi a grande guerra que determinou a sua falência.

A moção votada no congresso da CGT francesa de 1908, em Marselha, perante a ameaça de conflagração, vem oficializar a posição dos trabalhadores organizados. O reforço dos exércitos tinha como objectivo reprimir ou substituir os trabalhadores em greve. A ameaça de guerra constituía apenas uma manobra da burguesia, tendente a perpetuar o seu domínio, à qual a classe operária responderia com a greve geral. ${ }^{25}$

No contexto nacional, muito embora muitos socialistas, e até anarquistas, fossem conquistados pela idéia de uma guerra civilizacional contra o despotismo dos impérios centrais, a generalidade dos sindicalistas mantiveram-se sempre contra a conflagração e a participação de Portugal na mesma.

Segundo O Sindicalista, no final de 1912 tiveram lugar "contra a guerra imponentíssimas reuniões de protesto, os comícios de Lisboa, Porto, Évora e Setúbal." Nestas foi "aprovada uma moção de repulsa pela eventual participação de Portugal na guerra e enviado um telegrama de solidariedade à CGT francesa". ${ }^{26}$

Todavia, o operariado não correspondia à esperança revolucionária dos seus dirigentes. A greve geral organizada pela CGT francesa não tivera a adesão esperada, determinando o desalento nas fileiras do movimento operário internacional. ${ }^{27}$

Quando os socialistas alemães e franceses votaram os créditos de guerra, os socialistas dividem-se. Em Portugal, a direcção parlamentar do PSP começa a apelar para a

\footnotetext{
25 "Vida social: França” in A Sementeira, Setembro de 1908, p. 15

${ }^{26}$ "Contra a guerra imponentíssimas reuniões de protesto, os comícios de Lisboa, Porto e Évora e Setúbal." in $O$ Sindicalista, 22 de Dezembro de 1912, p. 1.

27 A imprensa operária portuguesa procurava relativizar a derrota e recusar a decretada falência do sindicalismo revolucionário, sublinhando o curto espaço de tempo que houve para organizar a greve geral francesa. Concluem, ainda assim, que "os acontecimentos mostram-nos ser necessário trabalhar e muito, ser preciza uma ativa propaganda (...). O número dos enérgicos, dos conscientes é pequeno, limitado, mas não constitue isso razão para afrouxar na luta." "Em França, a confederação e a greve geral" in O Sindicalista, 29 de Dezembro de 1912, p. 1.
} 
necessidade de respeitar os compromissos internacionais, ou seja, o tratado com a Inglaterra. Mas se o conselho central se inclinava para posições antigermanófilas, patentes no órgão central do partido, O Combate, $A$ Voz do Povo, no Porto, defenderá irredutivelmente a orientação antibelicista ao longo da guerra, manifestando o seu apoio ao manifesto de Zimmerwald e, posteriormente, às condições de paz bolchevistas.

Não foram apenas os socialistas a contradizer a sua inicial posição antibelicista. Também houve anarquistas partidários da guerra. Internacionalmente foram representados por Kropotkine, que alegava a necessidade de combater o despotismo alemão. De facto, o argumento da guerra civilizacional, que tinha por objectivo defender as conquistas das revoluções democráticas e liberais, unia republicanos, parte dos socialistas e também alguns libertários.

No contexto nacional, Emílio Costa foi o acrata que mais se destacou na defesa desta posição, tendo inclusivamente assinado o célebre Manifesto dos dezasseis, em que diversas personalidades do campo acrata dão o seu apoio aos aliados. No seu jornal, O Germinal, levou a cabo polémica com aqueles anarquistas que seguindo a posição de Malatesta, responsável pelo Manifesto contra a guerra, mantinham intransigentemente a sua posição anti-guerrista.

Este autor chamava a atenção para a necessidade dos anarquistas tomarem uma posição pragmática, apoiando as democracias liberais contra os estados autocráticos, acusando os "ortodoxos» de se refugiarem num dogmatismo verbal totalmente ineficaz. ${ }^{28}$ No fundo, propunha que os seus camaradas apoiassem o regime que pretendiam abolir.

Todavia, se alguns intelectuais sentiam que a sua liberdade poderia ser ameaçada pelo retrocesso que significaria a vitória dos impérios centrais, os libertários no meio operário não tinham razões para pensar que o despotismo alemão seria pior que o «rachasindicalistas» de Afonso Costa. ${ }^{29}$

Face à famosa carta de Kropotkine (justificadora do intervencionismo), interrogam-se os "anarquistas do Norte»" "que sucedeu nos últimos dois anos que possa justificar tal mudança de opinião?" E criticavam o facto de os anarquistas se dignarem "a discutir a

\footnotetext{
${ }^{28}$ Emílio Costa. “Os Anarquistas e a guerra Europeia”, in Germinal, 1 de Janeiro de 1915, p. 1.

${ }^{29}$ Governante e destacado dirigente republicano, liderou a fase de implantação do regime.

${ }^{30}$ No Norte do país, e particularmente no Porto, os anarquistas haviam ingressado nas associações de classe e eram os principais responsáveis pela introdução do Sindicalismo Revolucionário no movimento operário.
} 
embrulhada da política internacional e a comparar os governos uns com os outros, para tentar provar que um governo, ou uma forma de despotismo, deve ser preferido a outro."

O anarquismo operário sublinha o carácter classista desta divergência de orientação, criticando o facto de Kropotkine não se preocupar com a "situação dos trabalhadores nesta emergência ou depois dela", de não fazer "efectivamente referência alguma aos trabalhadores." ${ }^{31}$

De facto, a origem de classe e o íntimo envolvimento destes libertários nas associações de classe, por influência do sindicalismo revolucionário, terá determinado que $A$ Aurora, órgão privilegiado do anarco-sindicalismo durante a guerra, fosse dos mais aguerridos combatentes da guerra e da participação portuguesa na mesma, ainda que fossem secundados por outros grupos, como A Sementeira, e apoiados igualmente por alguns intelectuais, entre os quais se destaca Neno Vasco. ${ }^{32}$

Contudo, os militantes que se mantinham intransigentemente antiguerristas estavam cada vez mais isolados. Os socialistas preparavam-se para acompanhar os seus camaradas internacionais, apoiando o regime. E até a CGT francesa, a inspiração do Sindicalismo Revolucionário português, acabaria por sucumbir.

No inicio de 1915, Pierre Monatte, n'“um documento notável”, conta como "no decorrer dos últimos 5 meses" viu com assombro o comité confederal admitir pura e simplesmente, sem protesto, que o seu secretário geral aceitasse uma missão oficial como comissário da nação. Como algumas semanas mais tarde a comissão confederal, enviada a Bordéus, consentiu em fazer uma excursão de conferências por conta do governo. Como militantes sindicalistas e funcionários adoptaram uma linguagem digna dos mais puros nacionalistas. E como, finalmente, o comité confederal negou a sua simpatia aos esforços tentados para concertar a paz, aos socialistas dos países neutros. As nossas organizações centrais na França e na Alemanha, a CGT e os Partidos Socialistas, a União Sindical Internacional e a Internacional Socialista, "firmaram a sua bancarrota". ${ }^{33}$

\footnotetext{
31 “O carácter da presente conflagração", in A Aurora, 3 de Janeiro de 1915, p. 1.

${ }^{32}$ Gregório Nazianzeno Moreira de Queirós Vasconcelos, cujo o pseudónimo era Neno Vasco, virá a sintetizar os ensinamentos da participação dos anarquistas no movimento sindical, e paralelamente da guerra e da Revolução Russa, no texto mais esclarecedor sobre a introdução do anarco-sindicalismo em Portugal. Marcado indubitavelmente pelo pensamento de Malatesta, com quem trocava correspondência directa, a sua obra póstuma - Concepção Anarquista do Sindicalismo - oferece uma retrospectiva geral sobre o movimento sindical e sua relação íntima com o anarquismo, que neste período está em crescimento.

33 "Fala um revolucionário francês: a nossa atitude perante a guerra" in Aurora, 17 de Janeiro de 1915, p. 1.
} 
Em Portugal, a UON, criada em Março de 1914 com base numa unidade forçada e artificial, não conseguiu muito mais do que editar um manifesto contra a conflagração. Este, contudo, reflecte a orientação do Sindicalismo Revolucionário, que procurava conciliar de alguma forma as bases trabalhadoras do PSP e o anarquismo operário. Porém, era o embrionário anarco-sindicalismo que que se tornava cada vez mais atractivo para os trabalhadores portugueses devido ao seu intransigente antiguerrismo, suplantando paulatinamente a idéia de um sindicalismo independente e congregador de diferentes tendências ideológicas.

A rejeição dos argumentos liberais de defesa da guerra veio introduzir um novo elemento de distinção no movimento operário, mas desta vez mais classista que doutrinal. De facto, se intelectuais anarquistas e socialistas preteriram os interesses dos trabalhadores em nome das «conquistas civilizacionais burguesas», foram poucos os dirigentes operários que se deixaram enganar.

Todavia, se numa primeira fase as teses anti-intervencionaistas se enquadravam perfeitamente nos postulados obreiristas de Amiens, quando a CGT francesa traiu a causa antiguerrista, foi o anarquismo operário, influenciado directamente por Enrico Malatesta, que orientou a luta contra a mobilização.

A Primeira Grande Guerra determinou o fim de um ciclo na história europeia. Desde os princípios do século que as tendências reformistas e revolucionárias coexistiam com dificuldade ou se digladiavam nos partidos e no movimento sindical. Os bolcheviques abriram caminho à cisão ao abandonarem as posições dos mencheviques. A conflagração europeia determinou que outras facções seguissem o seu exemplo. A Internacional seria substituída e a luta de classes adoptou para sempre características claramente distintas.

A guerra europeia motivou a falência do Sindicalismo Revolucionário enquanto movimento internacional, tendente a transformar-se num novo paradigma ideológico. Não só porque a greve geral revolucionária que impediria a guerra não teve lugar, mas também porque a inspiradora CGT Francesa traiu os seus princípios, à semelhança dos partidos socialistas. Sabemos que a partir dessa data os partidos comunistas e os sindicatos anarquistas, dividiram a liderança do movimento operário em praticamente todo o mundo. 


\section{O SINDICALISMO REVOLUCIONÁRIO E A REVOLUÇÃO RUSSA}

Depois da expectativa de que os trabalhadores europeus impediriam uma guerra imperialista ter sido tragicamente frustrada, uma nova esperança nasceu a Oriente. A crise revolucionária do primeiro pós-guerra levou os mais cépticos a acreditar que o sistema capitalista estava ameaçado.

Portugal não foi uma excepção. Não faltam os testemunhos do receio que governos republicanos, patronato e outras camadas da sociedade tiveram de uma revolução socialista. De facto, nos designados anos da ameaça vermelha o movimento reivindicativo do operariado criou uma tensão social inédita.

As greves corporativas revitalizavam a UON e os trabalhadores indiferenciados revoltavam-se desorganizadamente, assaltando os armazéns onde os açambarcadores faziam os géneros esperar uma nova alta dos preços.

O apoio do PSP ao governo da União Sagrada e a radicalização da sociedade determinada pelas consequências dramáticas da guerra permitirão aos revolucionários estender a sua influência a praticamente todo o movimento organizado. Nas Conferências Operárias realizadas em Abril de 1917, os sindicalistas revolucionários tomam a liderança da União Operária Nacional.

Nesse ano, em paralelo com vastos movimentos populares contra os açambarcamentos, terá inicio a segunda ofensiva operária do século $\mathrm{XX}$, que o exemplo russo tornará infinitamente mais ameaçadora.

A agitação e a propaganda operária radicalizam-se, para infelicidade da burguesia, que não descansava desde o Outubro Bolchevista. Em meados do ano, "reina uma agitação operária como não há memória." A imprensa operária regozija-se: "Aproxima-se a grande revolução. E nós, ao vermos despontar lá longe, esse sol radioso e bom, bradamos: Viva a revolução social iniciada na Rússia! Abaixo todos os governos burgueses!" ${ }^{34}$

O alastramento das lutas sectoriais conduzem a UON à preparação da greve geral de Novembro de 1918, "a greve de todos os consumidores contra a carestia de vida", que correspondeu a um esforço organizativo sem precedentes. ${ }^{35}$ A greve não foi geral, nem

\footnotetext{
34 "A agitação operária", in A Greve, 3 de Março de 1918, p. 1.

${ }^{35}$ VIEIRA, Alexandre. Subsídios para a história do movimento sindicalista em Portugal. Lisboa: Edições Base, 1977, p. 125.
} 
revolucionária, como os seus organizadores desejavam, reflectindo contudo um movimento interclassista e de expressão nacional.

Em Janeiro do ano seguinte, com a derrota do sidonismo ${ }^{36}$, a ala mais conservadora da sociedade portuguesa era derrotada pela reunificação do operariado com a pequena e média burguesia urbana, enquanto que na Europa a revolução social avançava para Ocidente.

Os governos republicanos do pós-guerra irão pôr em prática, pela primeira vez, uma séria política de reformas sociais, criando o Ministério do Trabalho, tutelado por um socialista - o camarada Augusto - que publicará uma vasta legislação social, na qual se destaca a instituição dos seguros sociais obrigatórios e as oito horas de trabalho.

Perante a política reformista, todavia, a UON declara: "não a hora não é de paz, mas de guerra ardente, contínua porque não há possibilidade de haver paz, nem harmonia, onde existe uma classe que pretende manter o regime económico actual, com todas as suas anomalias, e outra que luta animosamente, numa batalha incessante e cada vez mais viva, pela transformação desta sociedade, com o intuito de substituir as presentes instituições por outras com formas novas, progressivas, humanas." ${ }^{37}$

De facto, em 1919, a confrontação social ultrapassava os estreitos limites das reformas legais. As primeiras greves desse ano foram vitoriosas servindo de incentivo ao surgimento de novas lutas e à reorganização sindical. No dia 23 de Fevereiro, surge nas bancas um novo diário da responsabilidade da UON, A Batalha, que rapidamente se torna o terceiro jornal nacional. O número de adesões aos sindicatos não cessa de aumentar à medida que as lutas sectoriais se tornam cada vez mais alargadas.

A estruturação da UON vai-se ampliando e reforçando, mesmo em zonas do país onde o sindicalismo nunca se havia enraizado, como por exemplo Aveiro ou Coimbra, onde são criadas Uniões de Sindicatos Operários, à semelhança dos que acontecera em Lisboa, no Porto e em Évora entre 1909 e 1912. Em todas a orientação revolucionária afirma-se incontestável. $^{38}$

O patronato, por seu lado, determinado a perpetuar os fabulosos lucros de guerra, não aceitará as novas imposições governamentais. As associações patronais apelam para o

\footnotetext{
${ }^{36} \mathrm{O}$ Consulado de Sidónio Pais foi a experiêcia percurssora de um regime autoritário em Portugal.

${ }^{37}$ A Batalha, 12 de Julho de 1919, p. 1.

38 "Movimento operário em Coimbra" e "União dos Sindicatos Operários", in A Terra, 18 de Julho de 1919, p. 1.
} 
seu boicote, desacreditando o reformismo e desafiando o operariado. Os trabalhadores lançam-se entusiasticamente na luta, com o objectivo de impor a aplicação da lei das oito horas, ao mesmo tempo que procuram acompanhar com os seus salários a contínua subida dos preços dos géneros.

No 1 o de Maio, a UON mobiliza 30.000 trabalhadores numa manifestação para a época monumental, na qual se saúda a Revolução Soviética e se exige a "gradual e progressiva socialização da terra e da indústria". ${ }^{39}$

Em plena ofensiva operária, a 13 de Setembro de 1919, realiza-se em Coimbra o II Congresso Nacional Operário, onde finalmente é criada a Confederação Geral do Trabalho (CGT), organizando praticamente duas centenas de associações de classe, que representavam entre 85 e 90 mil trabalhadores.

Muito embora as teses tenham originado intenso debate, reflectindo as tendências contraditórias que se iam desenhando no seio da jovem CGT, o esforço conciliatório por parte dos militantes que não queriam ver a organização fragmentar-se no acto criador, fez perviver a doutrina que unia anarco-sindicalistas e bolchevistas no combate ao reformismo o sindicalismo revolucionário.

Contudo, assumido o carácter nitidamente revolucionário do movimento, restava saber que revolução queriam os sindicalistas. A revolução social já não era apenas uma quimera inspiradora, era uma realidade concreta que se ia aproximando à medida que a onda subversiva irradiava da Rússia bolchevique.

Pela primeira vez, a concretização da emancipação operária surgia como uma realidade atingível. A viragem que essa constatação representa na construção ideológica, o debate que provocará no seio de todas as escolas socialistas e a transformação que determinará nos princípios de muitos militantes, começa a reflectir-se no pós-guerra.

Nos primeiros anos após a vitoria bolchevique, reticências teóricas à parte, toda a imprensa operária rejubilava com a onda revolucionária que avassalava a Europa. Mais do que elogiar, a propaganda esforçava-se por usar a revolução bolchevique como um catalizador do movimento reivindicativo.

Até $A$ Sementeira, um dos principais periórdicos acratas, afirmava que "depois de Lénine, Trotsky e seus amigos" deixarem de se intitular "governo, mas "soviet dos

\footnotetext{
${ }^{39}$ A Batalha, 2 de Maio de 1919, p. 1.
} 
comissários do povo»" o próprio Lisitchine (anarquista russo) defendia que a imprensa burguesa não se enganava ao falar da "«anarquia» russa." ${ }^{40}$ Todavia, à medida que o regime soviético se vai consolidando, os libertários começam a demarcar-se de alguns dos seus postulados, nomeadamente do conceito de ditadura do proletariado.

A Batalha - órgão central da recém criada CGT portuguesa - mantem uma posição dúbia. Em 1919 publicava em primeira página, lado a lado, uma carta de Romain Rolland e outra de Malatesta, que defendiam posições antagónicas face à Revolução Russa. O primeiro agradecia ao povo russo que conquistando a sua liberdade trabalhava para a emancipação de todos os europeus e o segundo condenava a ditadura do proletariado, comparando-a a todas as outras. ${ }^{41}$

A 26 de Julho de 1920, A Batalha publica uma carta de Kropotkine aos operários da Grã-Bretanha, introduzindo-a com a afirmação peremptória: “O facto da república dos sovietes nos ser bastante simpáctica e representar para nós um enorme passo para adiante não nos restringe a faculdade de crítica". Kropotkine defendia que o "comunismo estatista, estritamente centralizado, com um governo de ferro que realiza a ditadura dum partido" fracassara. Na sua opinião "a imensa obra construtiva exigida por uma revolução social (...) exige o saber, o cérebro e a colaboração voluntária de toda uma massa de forças locais e especializadas". ${ }^{42}$

Durante o verão desse ano, porém, o diário sindical publicou inúmeras opiniões que contrariavam ou fundamentavam o testemunho de Kropotkine, destacando-se os artigos de G. M. Serrati ${ }^{43}$, Anatole France ${ }^{44}$, Salvadore Ségui ${ }^{45}$ e os comunicados de Frossard e Cachin. ${ }^{46}$ A análise da vitória bolchevique instala-se no seio d'A Batalha pela pena de militantes estrangeiros.

Entretanto, um grupo de militantes disposto a levar o movimento às suas máximas consequências decide fundar uma organização própria - a Federação Maximalista

\footnotetext{
40 "A Nova Grande Revolução", in A Sementeira, Janeiro de 1918, p. 1-2.

${ }^{41}$ A Batalha, 19 de Setembro de 1919, p. 1.

42 "A Opinião de Kropotkine Acêrca da Rússia Vermelha" in A Batalha, 26 de Julho de 1920, p. 1.

${ }^{43}$ G.M. Serrati "Sobre a Rússia Vermelha, Primeiras Impressões Moscovitas" in A Batalha, 2 de Agosto de 1920, p. 1.

${ }^{44}$ Anatole France "Pela Rússia Vermelha", in A Batalha, 2 de Setembro de 1920, p. 1.

${ }^{45}$ Salvador Segui, “A Organização Sindical em face do Partido Socialista, em face da Revolução Russa”, in $A$ Batalha, 29 de Setembro de 1920, p. 1.

46 "Impressões da Rússia, O que Frossard e Cachin dizem àcêrca da república dos Sovietes" in A Batalha, 19 de Agosto de 1920, p. 1.
} 
Portuguesa - não pretendendo esperar a resolução do impasse em que se via imergida a CGT. Em Maio de 1919, há já notícia de diversos conselhos maximalistas na grande Lisboa Campo de Ourique, Meia Laranja, Belém, Oeiras, etc. E em Julho desse ano já se previa a publicação do semanário A Bandeira Vermelha.

A Federação Maximalista Portuguesa, tendo por objectivo a defesa da causa de Outubro através da divulgação das idéias dos principais líderes do regime soviético, deu um especial destaque nas páginas d'A Bandeira Vermelha à legitimação do poder proletário em ditadura, recorrendo a testemunhos de figuras proeminentes do sindicalismo e do anarquismo, numa tentativa de mostrar que o bolchevismo estava em sintonia com as idéias defendidas pelos sindicalistas, que "o Sovietismo" era a "fórmula slava do sindicalismo operário ocidental" ${ }^{47}$, que "O Sindicalismo Revolucionário é o mesmo que sovietismo". ${ }^{48}$

Os revolucionários desejavam a revolução, era por isso que procuravam encontrar afinidades entre o sovietismo vencedor e o sindicalismo. Contudo, à medida que a Revolução Russa se desenvolvia, as perspectivas diferenciavam-se, inviabilizando um consenso. Estes militantes viam-se confrontados com a necessidade de tomar uma posição face ao maior acontecimento social a que tinham assistido, o que na data parecia implicar deliberar sobre o carácter da sua própria revolução. Até 1921, a decisão revelou-se difícil de tomar, originando debates e conflitos que acabaram por dividir o movimento.

Foi só em Fevereiro de 1920 que, numa "importantissima reunião (...) se definiu pela primeira vez oficialmente a posição dos trabalhadores portugueses em face do bolchevismo". A Batalha finalmente esclarecia: "não somos bolchevistas. Acima de tudo somos sindicalistas revolucionários." Não deixava, porém, de advertir que essa tomada de posição não significava hostilidade à Revolução Russa: "bem pelo contrário seguimos atentamente a marcha do movimento procuramos assimilar os ensinamentos que dela resultam e apoiaremos sempre a Revolução contra os ataques da Internacional negra do capitalismo e do militarismo." ${ }^{49}$

Este comunicado reflecte que quando os anarquistas portugueses se apercebem do poder de atracção que o leninismo exercia sobre o designado sindicalismo independente

\footnotetext{
${ }^{47}$ Manuel Ribeiro, "Novas Tendências Sociais", in Bandeira Vermelha, 7 de Outubro de 1919, p. 1.

${ }^{48}$ Citação de R. Louzon in Bandeira Vermelha, 2 de Outubro de 1919, p. 1.

${ }^{49}$ A Batalha, 16 de Fevereiro de 1919, p. 1.
} 
dão início à batalha ideológica que irá marcar o entre-guerras e dividir o operariado, entre anarquismo e bolchevismo.

A Sementeira ${ }^{50}$ responde à pergunta lançada por Pierre Monatte ao Movimento Operário Francês - "O Soviet é porventura coisa muito diversa da União Local de Sindicatos?" - defendendo que receava "certas superfetações políticas, resultantes do dualismo da organização económica (soviet económico ou sindicato) e da organização política centralizada (sindicato político)." ${ }^{51}$

A Comuna $^{52}$ publica a carta de Malatesta, que define a posição dos anarcosindicalistas, ao distanciar-se da propaganda contra-revolucionária mas também dos postulados leninistas, nomeadamente no que respeita à necessidade da ditadura do proletariado. $^{53}$

Com a constituição da Internacional Comunista e das suas 21 Condições, a redacção d'A Batalha reafirma peremtoriamente a sua posição. Numa série de editoriais sob o título O Caminho a Seguir, reafirma o repúdio anarco-sindicalista por toda e qualquer espécie de ditadura, exercida pela "burguesia ou proletariado". ${ }^{54}$

$\mathrm{Na}$ data, A Batalha publicava a obra de Neno Vasco, que se correspondia directamente com Errico Malatesta, - Concepção anarquista do Sindicalismo - que define, com uma clareza invulgar, os postulados teóricos deste novo caminho a seguir. ${ }^{55}$

Este autor fora acérrimo defensor do Sindicalismo Revolucionário, tendo sido dos poucos intelectuais anarquistas que não houvera cedido ao intervencionismo, apoiando a corrente anarco-sindicalista que se fortalecia no Porto e no seio das juventudes.

Na data, chegou mesmo a ser acusado por Eduardo Gilimón, em La Protesta de Buenos Aires, de defender "a neutralidade absoluta e passiva dos anarquistas nos sindicatos, por apelar à união de todos os operários no terreno da luta de classes e a liberdade para todos, dentro do sindicato." 56

\footnotetext{
${ }^{50}$ Hilário Marques (intelectual anarquista) é director de $A$ Sementeira.

${ }^{51}$ "Na Hora da Luta”, in A Sementeira, Junho de 1919, p. 1.

${ }^{52}$ Manuel Joaquim de Sousa (principal dirigente anarco-sindicalista) é director de A Comuna.

53 "Uma carta de Malatesta" in A Comuna, 30 de Maio de 1920, p. 4.

${ }^{54}$ Gil Gonçalves, " O Caminho a Seguir Deve Ser a Preparação dos Elementos com que Há de fazer-se a Revolução", in A Batalha, 22 de Dezembro de 1920, p2.

${ }^{55}$ Esta obra tem sido traduzida e editada em vários países, constituindo um marco incontornável da história libertária. Ainda hoje é possível encontrar citações da mesma em numerosos órgãos de propaganda anarquista, por todo o mundo.

56 "O anarquismo nos sindicatos" in A Aurora, 20 de Junho de 1915, p. 1.
} 
Contudo, com a aprendizagem da Guerra e da Revolução Russa, o acrata reformulara a sua opinião. Em 1920 defende que aos anarquistas na organização sindical compete exercer "toda a sua actividade e influência, em prol do seu programa integral, sempre intransigentemente mantido afim de pesar com todo o seu peso e obter em todas as soluções o máximo de anarquismo." ${ }^{57}$

Se estava definido o papel dos anarquistas nos sindicatos, também estava esclarecido o papel dos sindicatos na anarquia. Os anarco-sindicalistas apartavam-se do automatismo sindical, mas também das restantes tendências anarquistas, nomeadamente a harmonista liderada por Pedro Kropotkine, abrindo caminho para a conceptualização do anarcosindicalismo português.

Por outro lado, a conjuntura do pós-guerra, que determinava a radicalização do operariado e do patronato, bem como a expectativa revolucionária, colocava igualmente questões práticas prementes, nomeadamente sobre o modelo organizacional a adoptar pela CGT - que muitos achavam destinada a tomar o poder.

A discussão que mobilizou o 2o Congresso Nacional Operário reflectia as transformações que o próprio tecido industrial português sofria em consequência da guerra. A indústria moderna que timidamente se desenvolvia em contexto nacional criava uma massa de operários que procuravam uma organização de grande escala, com efectiva intervenção política, enquanto que os antigos artífices da indústria tradicional continuavam a ver no ofício a mais eficaz forma de organização.

Se eram estes últimos que ainda mantinham alguma capacidade reivindicativa frente a um patronato igualmente débil e desorganizado, os dirigentes e ideólogos do movimento preferiram apoiar os primeiros, uma vez que para estes tratava-se não de decidir o protótipo de uma organização de resistência, mas de optar pelo modelo ideal de gestão da nova sociedade que a onda revolucionária traria por fim a Portugal.

\section{O SINDICALISMO REVOLUCIONÁRIO PERANTE A REACÇÃO PATRONAL}

No final de 1919, com a fundação da CGT, os dirigentes operários acreditam que “uma nova era começa para o proletariado português. A confederação conseguiria (...)

\footnotetext{
${ }^{57}$ Neno Vasco. Concepção anarquista do sindicalismo. Lisboa: A Batalha, 1920. p. 133-134.
} 
congregar dispersas energias em grandes núcleos de resistência capazes de afrontar a coligação patronal que reage desesperadamente nos paroxismos da agonia." ${ }^{58}$

Porém, no ano de 1920, as condições do fluxo grevista eram claramente distintas. O operariado organizado tinha de enfrentar um patronato bem longe da agonia e consciente de que a sua união era indispensável para a derrota dos trabalhadores.

Os industriais organizam-se na Associação Industrial Portuguesa e na Confederação Patronal, ao mesmo tempo que, ao contrário dos operários, tutelados progressiva e crescentemente pelo anarco-sindicalismo, darão uma maior atenção à esfera política, fazendo cair ministérios republicanos e promovendo os seus próprios representantes.

O ano começa com um novo ciclo de reivindicações salariais e com o agravamento da tensão social. As lutas sindicais ganham contornos subversivos e os levantamentos populares voltam a surpreender a sociedade.

Este movimento foi o canto do cisne da ofensiva operária do pós-guerra. A partir desta data as explosões do proletariado desorganizado irão sobrepor-se à acção da CGT que, perdendo progressivamente capacidade mobilizadora face ao aumento do desemprego, à crise económica e ao esgotamento da táctica reivindicativa, que se via ultrapassada pela contínua inflação, irá afundar-se em conflitos que ultrapassarão as divergências ideológicas, para caírem em questiúnculas pessoais.

Derrotado o movimento, Sérgio Príncipe - líder da Confederação Patronal - apela para "acções enérgicas, uma vez que os meios de acção pacífica se tinham esgotado" ${ }^{59}$ Após a tentativa fracassada de Álvaro de Castro e António Maria da Silva de tentarem formar governo, é um coronel - António Maria Baptista - que irá satisfazer os desejos do patronato, com o programa «ordem pública, ordem pública e ordem pública». ${ }^{60}$

Em meados do ano, muitos destacados dirigentes estão presos nas prisões da relação do Porto e no Limoeiro. Em Évora e Beja, os direitos de associação estão suspensos. $A$ Batalha e $O$ Combate são impedidos de circular e $A$ Comuna é perseguida nas ruas de Lisboa. ${ }^{61}$ Os comícios públicos não se realizam "devido à crise política que se atravessa, visto

\footnotetext{
58 "Lançam-se as bases da Confederação Geral do Trabalho" in A Batalha, 16 de Setembro de 1919, p. 1.

${ }^{59}$ Associação de classe do Pessoal dos caminhos-de-ferro do Sul e Sueste, A greve de 30 de Setembro de 1921: a atitude e o procedimento da CGT, p. 4-5.

${ }^{60}$ MEDEIROS, Fernando. A sociedade e a economia portuguesas nas origens do salazarismo. Lisboa: A Regra do Jogo, 1978, p. 221.

61 "Reacção Capitalista" in A Comuna, 30 de Maio de 1920, p. 4.
} 
que nenhuma autoridade os consente." "Pertencer-se a uma comissão de melhoramentos ou aos próprios corpos gerentes de uma classe, constitui um crime punível pelos dirigentes militares e reaccionários, com a transferência ou com outros castigos." ${ }^{62}$

A CGT procurará revigorar a sua influência na sociedade portuguesa, promovendo a agitação em torno da "questão das subsistências», ao mesmo tempo que aposta em movimentos de interesse público, em detrimento das greves corporativas.

Perante o malogro da prática reivindicativa, a central sindical chegava a um impasse, dando mostras de uma real desorientação. Apesar das grandes lutas estarem há muito ausentes das páginas d'A Batalha, quando em Janeiro de 1921, o congresso da Confederação Patronal espelha o perigo dos seus planos para combater a CGT - que incluem a criação de milícias tipo Barcelona, a corrupção de militantes ou a espionagem - os dirigentes operários continuam a proclamar que "se for necessário partir para a confrontação talvez os operários estejam melhor preparados que os patrões." ${ }^{63}$

Ao contrário do patronato, que se organizava na defesa dos seus interesses, o operariado desde as derrotas de 1920 que dava mostras de ter recuado ao estreito corporativismo. Nas páginas d'A Batalha passa a ser predominante a crítica dos dirigentes às corporações operárias, transparecendo que o modelo organizacional votado em Coimbra, que pressupunha a criação de federações de indústria e de sindicatos únicos, não se havia concretizado. $^{64}$

É exactamente ao longo deste mesmo período que a discussão teórica tomará um tom mais agressivo. Nas páginas d' A Bandeira Vermelha reflectir-se-á o azedar das relações entre anarquistas e maximalistas, mesmo antes d' $A$ Batalha tomar uma posição. Em meados do ano de 1920, os maximalistas encontram-se já "enojados da leviandade com que em algumas publicações portuguesas libertárias se escreve sobre bolchevismo." Em Março do ano seguinte, partem para a construção do que esperavam vir a ser uma nova vanguarda política - o Partido Comunista Português - já que os dirigentes anarco-sindicalistas recusavam à CGT esse papel.

\footnotetext{
${ }^{62}$ Associação de classe do Pessoal dos caminhos de Ferro do Sul e Sueste, A greve de 30 de Setembro de 1921: a atitude e o procedimento da CGT, p. 6-16.

63 "Sobre o congresso da Confederação patronal" in A Batalha, 11, 12, 13 e 15 de Janeiro de 1921, p. 1.

64 "A Confferencia Inter-Sindical do Porto", in A Batalha, 2,3, 4 e 6 de Janeiro de 1921, p. 1.
} 
A CGT, por seu lado, na famosa Nota Oficiosa que faz publicar, Em face dum novo Partido Político, é clara ao declarar que "o proletariado, a caminho da sua emancipação pela libertação da tutela dos senhores de hoje, não quer criar novas cadeias onde os prendam, amanhã novos senhores". ${ }^{65} \mathrm{O}$ conflito instala-se nas várias organizações, sendo expulsos dos seus cargos alguns militantes que ingressaram no PCP, havendo outros, contudo, que pela influência que exerciam nas suas associações de classe, se mantiveram no meio sindical.

No III Congresso Nacional Operário, de 1922, é confirmada a hegemonia anarcosindicalista, que ganhava terreno no seio do movimento desde a conflagração, quando foi a única tendência coerente e permanentemente antiguerrista, e se encontrava em maioria na direcção, desde que Manuel Joaquim de Sousa, seu mais destacado dirigente, houvera sido eleito Secretário-Geral da CGT em 1919.

A tese Organização Social Sindicalista e a resolução de filiar a CGT na Associação Internacional dos Trabalhadores (AIT) anarquista veio oficializar a orientação da central sindical. A doutrina sindicalista revolucionária, que desde 1914 congregava as diferentes tendências ideológicas do movimento operário, havia sido suplantada pela ala mais sectária da direcção, afastando os reformistas e radicalizando os bolchevistas.

No interior da CGT, os vencedores do Congresso da Covilhã não mereciam o apoio incondicional e maioritário dos militantes da organização. Os sindicalistas "puros», não anarquistas, teriam preferido que a CGT não se filiasse em nenhuma das Internacionais, e viam com maus olhos o sectarismo anarco-sindicalista que invalidava alianças com as restantes forças democráticas da sociedade portuguesa no combate ao avanço do conservadorismo. ${ }^{66}$

As divergências ideológicas, o agravamento da crise económica e o consequente refluxo do movimento operário levaram a CGT a perder, de 1919 a 1923, 45.000 inscritos. ${ }^{67}$ Depois do afastamento dos bolchevistas, a direcção da central será disputada por anarco-

${ }^{65}$ Comité Confederal, “Em Face de um Novo Partido Político, Nota Oficiosa da Confederação Geral do Trabalho", in A Batalha, 17 de Julho de 1921.

66 “Pela parte que me diz respeito penso e continuo a ser partidário da adesão a uma Internacional operária, onde possam coabitar todas as centrais de sindicatos, isto é, uma central de sindicatos que não seja tutelada por anarquistas, nem por socialistas, nem tão pouco por comunistas (...) Penso que a Internacional deve corresponder ao que se exige da Central sindical no plano nacional. Ora como nenhuma das Internacionais existentes reúne semelhantes características, daí o fundamento da nossa posição, que, como se vê, não é de neutralidade, mas de combate" "A situação dos operários portugueses: Entrevista a Alexandre Vieira" in Diário de Lisboa, 14 de Fevereiro de 1933.

${ }^{67}$ OLIVEIRA, César. O Operariado e a Primeira República (1910-1924). Porto: Afrontamento, 1977. p. 175-188. 
sindicalistas e "sindicalistas puros», oscilando entre o apoliticismo e o apoio táctico à esquerda republicana, perdendo progressivamente a sua influência e capacidade de mobilização.

A greve geral revolucionária para a qual a manchete d' $A$ Batalha apelava no dia 28 de Maio de $1926^{68}$, foi desconvocada pelo próprio órgão operário do dia seguinte, após a ameaça de encerramento dos sindicatos e prisão dos dirigentes que Mendes Cabeçadas lançou como primeiro repto do regime fascista a um movimento operário incapaz de reagir. $^{69}$

\section{CONCLUSÃO}

No pós-guerra, a corrente sindicalista revolucionária no seio da CGT francesa era encaminhada pela mão de Pierre Monatte - que defendera a independência do Sindicalismo Revolucionário no congresso anarquista de 1907, e se mantivera fiel aos seus princípios, demitindo-se da CGT quando esta cedera ao intervencionismo em 1914.

De facto, no congresso de Lille de 1921, esta autoridade no seio da corrente revolucionária defende a adesão à Internacional Sindical Vermelha, confiante que as palavras de Lenine - "Il n'est pas vrai que les Russes imposent aux révolutionnaires des autres pays de copier servilement et fidèlement leur Révolution, et de l'accomplir à leur modèle. Allez plus loin que nous, me disait Lénine, dépassez-nous, faites mieux que nous, mais faites ${ }^{\prime \prime *}$ - garantiam a independência do movimento sindical. ${ }^{70}$

Em Novembro do ano seguinte, após o congresso do Partido Comunista Francês, Monatte volta a esclarecer a posição sindicalista revolucionária face à nova conjuntura criada pela guerra e a revolução russa. Colocando as conquistas revolucionárias do povo russo acima de qualquer divergência doutrinal, os sindicalistas revolucionários continuam a atribuir às associações de classe o papel determinante na luta de classes. Aceitando o auxílio

\footnotetext{
${ }^{68}$ Data do golpe militar que instaurou o regime fascista em Portugal.

${ }^{69}$ CARVALHO, David de. Os sindicatos operários e a república burguesa (1910-1926). Lisboa: Seara Nova, 1977, p. 240-243.

* "Não é verdade que os russos impõem aos revolucionários dos outros países copiar servilmente e fielmente sua Revolução e levar a cabo o modelo deles. Vá mais distante que nós, me disse Lênin, nos exceda, faça melhor que nós, mas faça." [Tradução dos editores]

${ }^{70}$ Pierre Monatte, Discours au congrès de Lille de la C.G.T. (30 juillet 1921) in Compte-rendu des travaux du XXII ${ }^{\circ}$ congrès national corporatif (XVI ${ }^{\circ}$ de la C.G.T.). Disponível em linha: http://www.marxists.org/francais/monatte/works/1921/07/monatte 19210730.htm\# ftn3
} 
das novas instituições revolucionárias, os partidos comunistas, mantêm irredutível a sua recusa em relacionar as diferentes organizações - a económica e a política.

Na sua opinião, a introdução de uma doutrina estranha ao sindicalismo enfraquece a acção das associações de classe, uma vez que afasta destas organizações de resistência operária os elementos com princípios diferentes, o que acontecera na CGT francesa, quando os anarquistas iniciaram a sua campanha contra a ditadura do proletariado e os métodos da revolução russa. ${ }^{71}$

Foi exactamente o que aconteceu em Portugal. O anarco-sindicalismo português atingira a sua maturidade e rendia o Sindicalismo Revolucionário. Quando a crise revolucionária do pós-guerra começa a esmorecer, e a eficácia do sindicalismo é posta em causa por um patronato cada vez mais unido, os anarquistas iniciam a sua batalha ideológica contra a "ameaça leninista», apontando as insuficiências e contradições da doutrina que inspirara o movimento operário desde 1909.

Paralelamente, a evolução do anarquismo operário de Malatesta, muitas vezes publicada na imprensa operária, reflecte-se sem dúvida na evolução ideológica do movimento sindical português, que é conduzido, de facto, pelos anarco-sindicalistas.

No congresso anarquista de Amesterdão, em 1907, este anarquista opunha-se já a Monatte, conquistado pela doutrina oficial da CGT francesa, afirmando que "o sindicalismo, mesmo ganhando consistência com o adjectivo revolucionário, só pode ser um movimento legal, movimento que luta contra o capitalismo no meio económico e político que o capitalismo e o Estado Ihe impõem. Não tem, portanto, saída, e nada poderá obter de permanente e geral." ${ }^{72}$

Os ensinamentos da Grande Guerra e da Revolução Russa irão tornar clarividente a sua posição face ao sindicalismo de inspiração francesa. O seu artigo Sindicalismo $e$ Anarquismo de 1922 encontra muitos pontos comuns com a obra de Neno Vasco, supracitada, nomeadamente na enunciação dos perigos do sindicalismo.

Para ilustrar os seus argumentos, Malatesta refere inúmeros exemplos concretos, com base na realidade italiana de então. Também Neno Vasco, ao fazer a crítica do

\footnotetext{
${ }^{71}$ Pierre Monatte, Declaration after the Paris Congress of the PCF in Bulletin Communiste, 9 de Novembro de 1922. Disponível em linha: http://www.marxists.org/archive/monatte/1922/declaration.htm

72 Intervenção de Malatesta no Congresso de Amesterdão. Publicada por Les Temps Nouveaux em 1907 e traduzida para português por Fernando A. S. Araújo. Disponível em linha:

http://www.marxists.org/portugues/malatesta/1907/10/05.htm
} 
Sindicalismo Revolucionário português, aponta os resultados práticos das suas insuficiências no contexto nacional.

A época do Sindicalismo Revolucionário estava definitivamente ultrapassada na Europa e em Portugal. Aliás, muito embora continuem a defender a unidade do movimento operário com base nos princípios de Amiens, a evidência dos acontecimentos transformara as idéias até dos seus mais fiéis defensores.

Esta idéia francesa, promovida a doutrina pelos seus defensores, constituira-se como um fenómeno transnacional, exportada inclusive para os Estados Unidos. O movimento operário português acompanhou a sua difusão e a sua evolução para o anarco-sindicalismo, acolhendo os grande debates em que se centraram os teóricos e dirigentes europeus. Os seus reflexos perpectuaram-se no tempo, determinando um Partido Comunista liderado por sindicalistas embuídos de apoliticismo e uma CGT anarco-sindicalista que nunca renunciou à independência ideológica do sindicalismo.

Todavia, a quimera sindicalista revolucionária foi animando cada vez menos militantes. Em 1927, antigos dirigentes sindicalistas fundavam novamente o Grupo de Propaganda Sindicalista, com os mesmos pressupostos de 1909. Em 1931, inspirados pelo Comité dos $22^{73}$, ainda sonham com um Núcleo de Estudos e Propaganda do Sindicalismo. ${ }^{74}$ Contudo, estas iniciativas não tiveram quaisquer repercussões no movimento operário português, senão a recordação de uma Idéia.

\footnotetext{
${ }^{73}$ Criado em 1930 com elementos oriundos da CGT francesa, anarco-sindicalista, da CGTU, comunista, e dos Sindicalistas Autónomos, preconizando a unidade orgânica com base nos princípios da Carta de Amiens. Chegou a editar Le Cris du People e a agrupar algumas centenas de militantes, mas não resistiu mais de um ano. ${ }^{74}$ Alberto Pedroso e António Ventura, Alexandre Vieira: 30 anos do sindicalismo português, p. 128.
} 